Research Papers

\title{
Effects of Spruce Budworm (Choristoneura fumiferana (Clem.)) Outbreaks on Boreal Mixed-Wood Bird Communities
}

\section{Effets des épidémies de Tordeuse des bourgeons de l'épinette (Choristoneura fumiferana (Clem.)) sur les communautés d'oiseaux de la forêt boréale mixte}

\author{
$\underline{\text { Lisa A. Venier }}^{1}, \underline{\text { Jennie L. Pearce }}^{2}, \underline{\text { Don R. Fillman }}^{3}, \underline{\text { Don K. McNicol }}^{3}$, and Dan A. Welsh ${ }^{4}$
}

\begin{abstract}
This study examined the influence of a spruce budworm (Choristoneura fumiferana (Clem.)) outbreak on a boreal mixed-wood bird community in forest stands ranging in age from 0 to $223 \mathrm{yr}$. We asked if (1) patterns of species response were consistent with the existence of spruce budworm specialists, i.e., species that respond in a stronger quantitative or qualitative way than other species; (2) the superabundance of food made it possible for species to expand their habitat use in age classes that were normally less used; and (3) the response to budworm was limited to specialists or was it more widespread. Results here indicated that three species, specifically the Bay-breasted Warbler (Dendroica castanea), Tennessee Warbler (Vermivora peregrina), and Cape May Warbler (Dendroica tigrina), had a larger numerical response to the budworm outbreak. They responded with increases in density of up to tenfold over 4 or 5 yr. No other species responded with more than a twofold increase in the same time period. These species also showed a functional response by breeding more frequently in young stands aged 1-21 yr and intermediate stands aged 22-36 yr as budworm numbers increased. Our data also suggested that many species profited to a lesser extent from budworm outbreaks, but that this effect may be too subtle to detect in most studies. We found evidence of a positive numerical effect in at least 18 additional species in one or two stand-age categories but never in all three for any one species. Given the numerical response in many species and the potential influence of budworm on bird populations because of the vast extent of outbreaks, we believe that the population cycle of spruce budworm should be considered in any evaluation of population trends in eastern boreal birds.
\end{abstract}

RÉSUMÉ. Cette recherche a pour but d'évaluer l'influence d'une épidémie de Tordeuse des bourgeons de l'épinette (Choristoneura fumiferana (Clem.)) sur une communauté d'oiseaux en forêt boréale mixte, dans des peuplements âgés de 0 à 223 ans. Nous nous sommes demandés si : 1) les profils de réponse des oiseaux concordaient avec l'existence de spécialistes de la tordeuse, c.-à-d. les espèces qui répondent de façon plus marquée - tant sur le plan quantitatif que sur le plan qualitatif - que les autres espèces; 2) la surabondance de nourriture permettait aux espèces de fréquenter des types de peuplements habituellement moins utilisés en raison de leur classe d'âge; et 3) la réponse à la tordeuse était limitée aux spécialistes ou si elle s'étendait à d'autres espèces. Nos résultats indiquent que trois espèces, soit la Paruline à poitrine baie (Dendroica castanea), la Paruline obscure (Vermivora peregrina) et la Paruline tigrée (Dendroica tigrina), ont eu des augmentations importantes d'effectifs qui coïncidaient avec l'épidémie de tordeuse. La densité de ces espèces a augmenté par un facteur de 10 en 4 à 5 ans. La densité des autres espèces n'a pas augmenté de plus du double pendant la même période. Les trois espèces de paruline ont aussi montré une réponse fonctionnelle en nichant plus souvent que d'habitude dans les jeunes peuplements (1-21 ans) et dans les peuplements d'âge intermédiaire (22-36 ans) à mesure que le nombre de tordeuses augmentait. Nos données

${ }^{1}$ Canadian Forest Service, ${ }^{2}$ Pearce \& Associates Ecological Research, ${ }^{3}$ Canadian Wildlife Service, ${ }^{4}$ (Deceased)

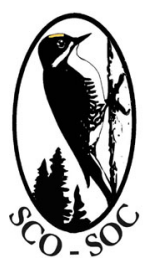

Sponsored by the Society of Canadian Ornithologists and Bird Studies Canada

Parrainée par la Société des ornithologistes du Canada et Études d'oiseaux Canada

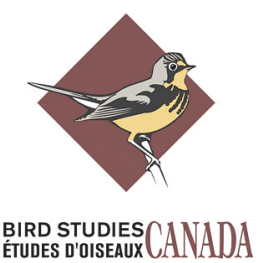


laissent aussi croire qu'un grand nombre d'espèces a profité, dans une moindre mesure, des épidémies de tordeuse, mais que cet effet est peut-être souvent trop faible pour être détecté. Nous avons également observé une augmentation des effectifs chez au moins 18 autres espèces dans une ou deux catégories de classe d'âge, mais jamais dans les trois catégories. Étant donné l'augmentation des effectifs chez de nombreuses espèces et l'influence potentielle de la tordeuse sur les populations d'oiseaux en raison de la vaste étendue des épidémies, nous croyons que le cycle des populations de Tordeuse des bourgeons de l'épinette devrait être pris en considération dans toute évaluation de la tendance des populations d'oiseaux boréaux de l'Est.

Key Words: boreal forest birds; spruce budworm; succession; boreal mixed woods; mapping census; Choristoneura fumiferana (Clem.)

\section{INTRODUCTION}

Forest landbirds are an integral part of the boreal ecosystem and play an important role in forest integrity and sustainability (Niemi et al. 1998). Thirty-seven of the 138 species of landbirds that regularly breed or winter in Ontario's Boreal Shield ecozone have been identified as priority species by Ontario Partners in Flight (2006). Most of the priority species are common boreal forest landbirds for which the Ontario Boreal Shield has a high conservation responsibility because a large proportion of these populations live in the region. Some high-priority species such as the Bay-breasted Warbler (Dendroica castanea) and the Canada Warbler (Wilsonia canadensis) have high vulnerability and have experienced population declines. The ecology of forest birds in the eastern boreal forest has not been well studied relative to other North American ecosystems, but assessing the status of and trends affecting forest landbirds in this region has become an important priority (Environment Canada 1995, Ontario Ministry of Natural Resources 2005). As well, forest landbirds have been proposed and used as an important tool in assessing the sustainability of forest management (Voigt et al. 2000, Holloway et al. 2004, Venier and Pearce 2004, Venier et al. 2007). For these reasons it is important to understand the ecological processes of the boreal forest that affect the population levels of this taxon.

In this paper we examine the effects of a spruce budworm (Choristoneura fumiferana (Clem.)) outbreak on a boreal mixed-wood bird community in stands representing a range of successional stages. Spruce budworm are a major driver of ecosystem dynamics, and their outbreaks have profound effects on forest composition and structure over very large areas (Blais 1983, Bergeron et al. 1995, Candau and Fleming 2005, MacLean and Andersen 2008). For example, 41 million ha of Ontario forest have been defoliated by spruce budworm at least once since 1941. Outbreaks occur with a basic oscillation of approximately $36 \mathrm{yr}$ (Candau et al. 1998). Forest disturbances such as spruce budworm outbreaks, fires, and harvesting all have a significant influence on forest age-class distribution, which in turn is an extremely important predictor of bird community composition (Welsh 1987, Helle and Mönkkönen 1990, Hobson and Schieck 1999, Venier and Pearce 2005). As well, a budworm outbreak has the direct effect of increasing food availability for many forest landbirds (Mitchell 1952, Dowden et al. 1953, Crawford and Jennings 1989). The interaction of forest stand age and response to spruce budworm outbreak can provide additional insight into the relationship between the bird community and budworm.

Several studies have documented the numerical response of individual bird species to outbreak levels of spruce budworm (Kendeigh 1947, Hensley and Cope 1951, Morris et al. 1958, Erskine1977, Morse 1978, Crawford et al. 1983); please see Appendix 1 for a summary. Several species have been called spruce budworm "specialists," including the Bay-breasted Warbler (Dendroica castanea), the Tennessee Warbler (Vermivora peregrina), and the Cape May Warbler (Dendroica tigrina), because of their large and consistent response (Welsh 1985, Morse 1989, Patten and Burger 1998). Some species have shown responses in some but not all studies, e.g., the Blue-headed Vireo (Vireo solitarius). In separate studies, the 
Blackburnian Warbler (Dendroica fusca) and the Yellow-rumped Warbler (Dendroica coronata) showed both positive and negative responses (Appendix 1); the negative response are attributed to competition with more abundant species (Morris et al. 1958, Morse 1989).

This study examined 18 9-ha plots ranging in age from $1 \mathrm{yr}$ since disturbance to $223 \mathrm{yr}$ since disturbance over the five years between 1979 and 1983, when spruce budworm levels transitioned from endemic to epidemic in this region. Data were collected intensively using mapping census techniques (IBCC 1970), with the result that this study provides one of the most in-depth examinations of the bird community response to spruce budworm of those currently in the literature. The intensive nature of the data collection and the relatively large number of plots allowed us to document the presence of a numerical response in a large number of species with greater confidence than was possible in previous studies, which commonly used low-intensity methods or lower replication. We were interested in three principal questions in relation to these data. First, were patterns of species response consistent with the existence of spruce budworm specialists, i.e., species that respond in a stronger quantitative or qualitative way than other species? Second, did the superabundance of food allow bird species to expand their habitat use into stand ages that were normally lesser used? Third, was the bird response to budworm limited to specialists, or was it more widespread?

\section{METHODS}

\section{Study area}

The study area is located north of Manitouwadge, Ontario, Canada, at $49^{\circ} 30^{\prime} \mathrm{N}, 86^{\circ} \mathrm{W}$, in the Boreal Shield ecozone (Fig. 1) in mixed coniferous and deciduous stands of the Central Plateau Region of the boreal forest (Rowe 1972). Plots of 9 ha were established in 18 upland mixed-wood stands that had a similar topography, similar soils and moisture regimes, and predisturbance vegetation that was a mixture of black spruce (Picea mariana), balsam fir (Abies balsamea), and aspen (Populus balsamifera or $P$. tremuloides). These stands represented an age gradient of natural regeneration from harvesting (1945-1979) and fire. The six oldest stands were of fire origin and varied in age from 60 to $223 \mathrm{yr}$. The
12 youngest stands ( $0-33 \mathrm{yr}$ ) had been harvested for merchantable conifer and aspen. One stand, aged $109 \mathrm{yr}$ in 1979, was harvested but not sampled in 1981 and then became a 1-yr-old stand in 1982. Stands were identified by their approximate age since disturbance. Sampling plots had one of two configurations: squares of $300 \times 300 \mathrm{~m}$ and rectangles of $500 \times 200 \mathrm{~m}$ with an area of $100 \times 100$ $\mathrm{m}$ removed from one corner. We classified the plots into three stand age categories, i.e., young, intermediate, and mature, based on time since disturbance in years. In 1979, the young stands were aged $1,4,6,8,9,11,15,17$, and $21 \mathrm{yr}$. Intermediateaged stands were $24,26,30$, and $36 \mathrm{yr}$. The mature plots were $60,109,150,151,179$, and $223 \mathrm{yr}$. Plot 109 (1979 and 1980) became plot 1 in 1982 and 1983 after it was logged in 1981.

\section{Bird sampling}

A mapping census technique (IBCC 1970) was used to identify species-specific territories in each of five years (1979 through 1983). Experienced observers visited plots seven to 10 times each year between 23 May and 7 July. Visits were made between dawn and 1000 Eastern Daylight Time. Visits lasted approximately 1-2 $\mathrm{hr}$. Transects were walked in alternate directions on successive visits, and visit times alternated between dawn and mid-morning. Visits were made by 10 different observers over the 5 -yr period. Each observer was assigned four or five plots depending on difficulty and traveling distance between plots. A single supervisor censused all plots at least once during each census season to confirm procedures, species identification, and territory boundaries.

Plots were gridded with $50 \mathrm{~m}$ spacing to help bird observers map the locations of observations. All birds seen or heard were indicated on a territory map. Simultaneous observations of more than one individual of a species were recorded to differentiate multiple individuals of the same species. Clusters were identified as a group of records of a species that, on final analysis of a species map, appeared to be associated with a territory held by one male. The minimum number of records required before a cluster was accepted as a territory was related to the number of valid visits and the migratory status of the species. For eight to 10 valid visits, three records were required, and for five to seven valid visits, two records were required. The number of valid visits is 
Fig. 1. Map of the study location.

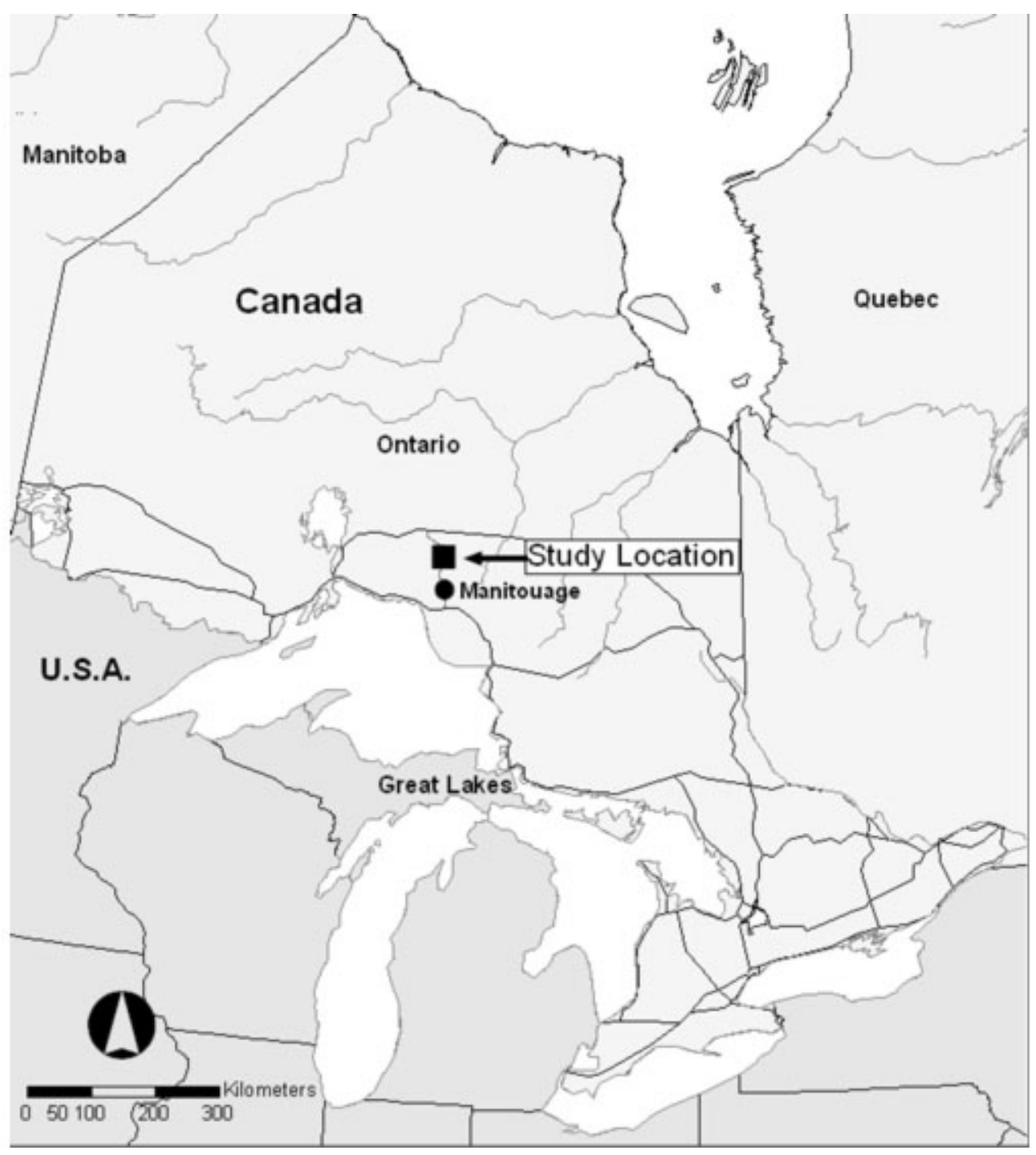

the number of visits on which the given species could have been observed; for example, early visits for a late migrant are not valid. The assignment of territories for resident species required only two records because of their secretive nature and earlier breeding habits. At least two records needed to be of high territorial significance for any territory, e. g., song. Territories that overlapped the plot edge were counted as fractional territories based on the amount of the territory contained in the plot. Plot maps from each visit were synthesized at the end of the season to generate a territory map for each species. If the observations for a particular individual did not meet the requirements for territory acceptance, that individual was recorded as a visitor on that plot. Birds were not sampled in plot 151 in 1979 and in plot 109 in 1981 . Otherwise, all plot-year combinations were sampled. 


\section{Budworm sampling}

Spruce budworm were sampled in 1982 and 1983 using standard techniques (Morris 1955). Extendable pole pruners were used to remove one $45-\mathrm{cm}$ branch tip from the mid-crown of each of three co-dominant balsam fir trees selected at random on each sample date. Branches were bagged in the field and returned to the laboratory, where they were examined, and all stages of all insect species were removed, identified, and enumerated. Budworm density was expressed as the number of insects per $45-\mathrm{cm}$ branch tip. Budworm were sampled on 17 June 1982 ( $n=342$ branch tips), and on $15,16,17,21$, and 23 June 1983 ( $n=342$ branch tips).

\section{Data analysis}

\section{Bird community analysis}

To assess the overall changes in the bird community as a function of increasing budworm through time, we calculated the total number of species and the total number of territories for each of the five study years. We also calculated the mean number of territories per plot for all species combined as a function of year for each of three stand-age categories. Using S-PLUS Version 7.0 software (Insightful Corporation, Seattle, Washington, USA), we developed a linear mixed regression model to examine the relationship between the number of territories per plot and the year and standage category. Year acted as a surrogate for the number of budworm and was identified as the fixed effect; plot, which was measured over five years, served as the random effect; and stand-age category provided an outer co-variate. We conducted this test with and without budworm specialists as part of the total.

\section{Budworm counts}

We compared the number of budworm per branch tip in three stand-age categories and in two years, 1982 and 1983, using a two-way ANOVA with replication and multiple comparisons with a simulation-based method. Data were transformed using a square root +0.5 transformation to improve the distribution of the residuals (Zar 1984).

\section{Bird response to budworm}

We examined the number of bird territories per plot as a function of mean budworm count per branch tip in balsam fir with year $(1982,1983)$ as a covariate using an analysis of co-variance.

\section{Individual species analysis}

Data were insufficient to allow for rigorous statistical analysis of the change in territories over time on an individual species basis. We examined plots of all species and stand-age category combinations to assess evidence of a response. We also compared the number of territories at the beginning of the study $(1979+1980)$ to the number of territories at the end of the study $(1982+1983)$ for the 30 most abundant species. Statistical comparisons were made using the Wilcoxon signedranks test for paired nonparametric data. $P$-values were used to indicate relative effect size but not to indicate statistical significance.

\section{RESULTS}

\section{Bird territory changes through time}

Sixty-six forest bird species had territories in the 18 study plots (Appendix 2). The total number of bird territories more than doubled from 1979 (598 territories) to 1982 (1259 territories), then dropped in 1983 to 1082 territories (Fig. 2). The number of species showed a similar pattern, increasing from 1979 to 1982 and then declining in 1983 (Fig. 2). The results from the linear mixed regression model indicated that there was a significant positive relationship between the number of territories per plot and the year (estimate $=0.137, \mathrm{df}=66, t$-value $=5.15, p<0.0001)$. The response variable was transformed with a square root plus 0.5 transformation to improve the distribution of the residuals of the fit. We included the stand-age category as an outer co-variate and saw no evidence of an interaction between stand-age category and the relationship between territories per plot and year (year $*$ intermediate, estimate $=0.034, \mathrm{df}=66, t$ value $0.739, p>0.463$ : year $*$ mature, estimate $=$ $0.036, \mathrm{df}=66, t$-value $=0.817, p>0.417)$, although the sample sizes were small within stand-age categories and the power to detect differences was probably low. Visually, the pattern of increase in 
territories appeared different in mature vs. intermediate and young plots (Fig. 3), which appeared to respond more slowly at first, with only moderate increases in territory density in 1980 and 1981, and then more rapidly in 1982 (Fig. 3).

\section{Budworm counts}

Budworm counts per balsam fir branch tip increased from 1982 (mean= 5.56, $n=396)$ to 1983 (mean= 9.17, $n=384$; two-way ANOVA: $F=20.38 ; p<$ 0.001 , df $=1$ ), suggesting that the outbreak was still occurring in 1983. Budworm counts differed among age classes $(F=13.23, p<0.001, \mathrm{df}=2)$. However, there was no evidence of an interaction between year and age class $(F=1.83, p>0.160, \mathrm{df}=2)$. Multiple comparisons based on simulations indicated that budworm counts in young stands (mean $=5.91, n=$ 290) were less than in both intermediate stands $($ mean $=6.94, n=153$; estimate $=-0.32, \mathrm{SE}=0.09)$ and mature stands (mean $=8.44, n=243$; estimate $=-0.44, \mathrm{SE}=0.08$ ), but that counts in intermediate stands did not differ from counts in mature stands (estimate $=-0.13, \mathrm{SE}=0.09$ ), although a trend is evident.

\section{Bird response to budworm}

Overall, there was a significant positive relationship between number of bird territories and mean budworm count per balsam fir branch tip $(F=4.278$ on 3 and $28 \mathrm{df}, p<0.013$, multiple $\mathrm{R}^{2}=0.314$ ). Budworm count was a significant predictor of the number of bird territories in $1982(t$-value $=2.814$, $p<0.008$ ), but not in 1983 ( $t$-value $=1.42, p=$ $0.168)$, although a trend was still apparent in 1983.

\section{Individual species}

Enormous increases in territory densities from 1979 to 1982 and in 1983 were shown by three species: the Bay-breasted Warbler, the Tennessee Warbler, and the Cape May Warbler (Fig. 4A-C). The largest absolute increase in territory number was observed for the Bay-breasted Warbler, which increased from approximately four territories per plot to more than 17 territories per plot in mature forest stands (a 4.7fold increase in 5 yr). Cape May Warblers were less abundant overall, but their mean number of territories increased from less than one territory per plot in 1979 to more than five territories per plot (a 10.4-fold increase in $4 \mathrm{yr}$ ). Tennessee Warblers increased 9.1-fold over 4 yr.

A positive increase in the numbers of territories for the Bay-breasted Warbler, Tennessee Warbler, and Cape May Warbler was observed in all three standage categories of plots (Fig. 4A-C). Cape May Warblers did not occur in the young and intermediate-aged plots from 1979 to 1981 , but appeared in 1982 (7.7 territories) and 1983 (four territories). Their abundance in 1982 in young and intermediate-aged plots was greater than in mature plots in 1979 (3.2). The number of Bay-breasted Warbler territories was low from 1979 to 1981 in the young and intermediate-aged plots and significantly higher in 1982 and 1983. Again, the number of territories in intermediate-aged plots in 1982 and 1983 (35.4, 54.9) exceeded the number of Bay-breasted Warbler territories in mature plots in 1979 (21.8). The response of these species in young and intermediate-aged stands was different than the response observed in mature stands. In young and intermediate-aged stands, the response occurred later in the progression of the outbreak, although, proportionally, the response was as strong or stronger (Fig. 4A,C) than observed in mature stands. Although Tennessee Warblers were more abundant in mature plots than in intermediate or young plots (Fig. 4B), they showed a proportionally higher response in younger plots than did Bay-breasted Warblers and Cape May Warblers.

When these three species were removed from the combined species data, the general pattern of increase in territory density remained (Fig. 5), and the statistically positive relationship between the square-root transformed number of territories per plot and the year continued (Fig. 5; linear mixed model, estimate $=0.296, \mathrm{df}=68, t$-value $=5.20, p$ $<0.0001)$.

We examined plots of the relationship between the number of territories and the year for all species and stand-age category combinations, and included plots here for a selection of species that were indicated in the literature to have responded to budworm outbreaks (Appendix 1) or that appeared to show an effect in our data. We found subtle patterns of territory increase for several species, e. g., the White-throated Sparrow (Zonotrichia albicollis) and the Ovenbird (Seiurus aurocapillus), although these patterns were generally evident in only one or two stand-age categories rather than all 
Fig. 2. Number of bird territories and the number of species in all 18 plots from 1979 to 1983.

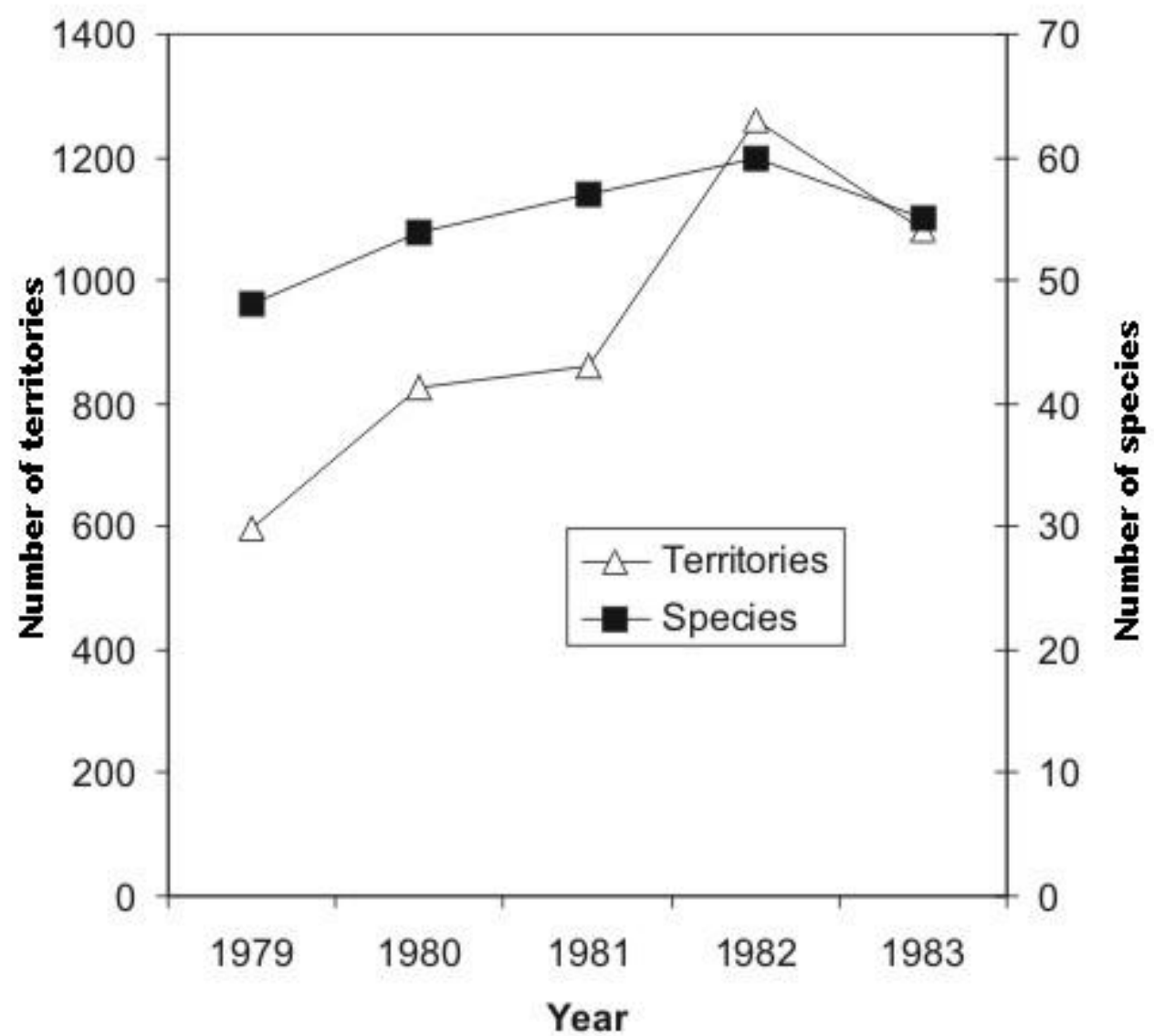

three (Fig. 6). In our results, many species showed a subtle response to the budworm outbreak. Cumulatively, the effect was quite strong (Fig. 5), although individual species responses were not always evident or measurable (Fig. 6, Table 1).

We found that 25 of 30 abundant species had more territories in $1982+1983$ compared with $1979+$ 1980; of these, nine species, including the Baybreasted Warbler, Tennessee Warbler, and Cape May Warbler, had Wilcoxon-based $p$-values of less than 0.05 (Table 1). Because mature and intermediate age classes contained only four plots each, we combined young and intermediate plots, and intermediate and mature aged plots for comparisons. Only Bay-breasted Warbler, Tennessee
Warbler, and Cape May Warbler had p-values below 0.05 for all young + intermediate + mature, young + intermediate, and intermediate + mature stand-age categories. All three species had $p$-values of 0.1 or less for the young stand-age category. As seen in Table 1 and Fig. 6, other species that showed some evidence of a positive response in young or intermediate-aged stands included the Whitethroated Sparrow, Ovenbird, Golden-crowned Kinglet (Regulus satrapa), American Redstart (Setophaga ruticilla), Black-and-white Warbler (Mniotilta varia), Veery (Catharus fuscescens), and Purple Finch (Carpodacus purpureus).

Because of the small sample sizes of mature plots, species that increased in mature plots alone were 
Fig. 3. Number of bird territories in each plot in young (triangle), intermediate (circle), and mature (square) stand-age classes. Lines indicate the mean in mature plots (solid), intermediate plots (dotted), and young plots (dashed).

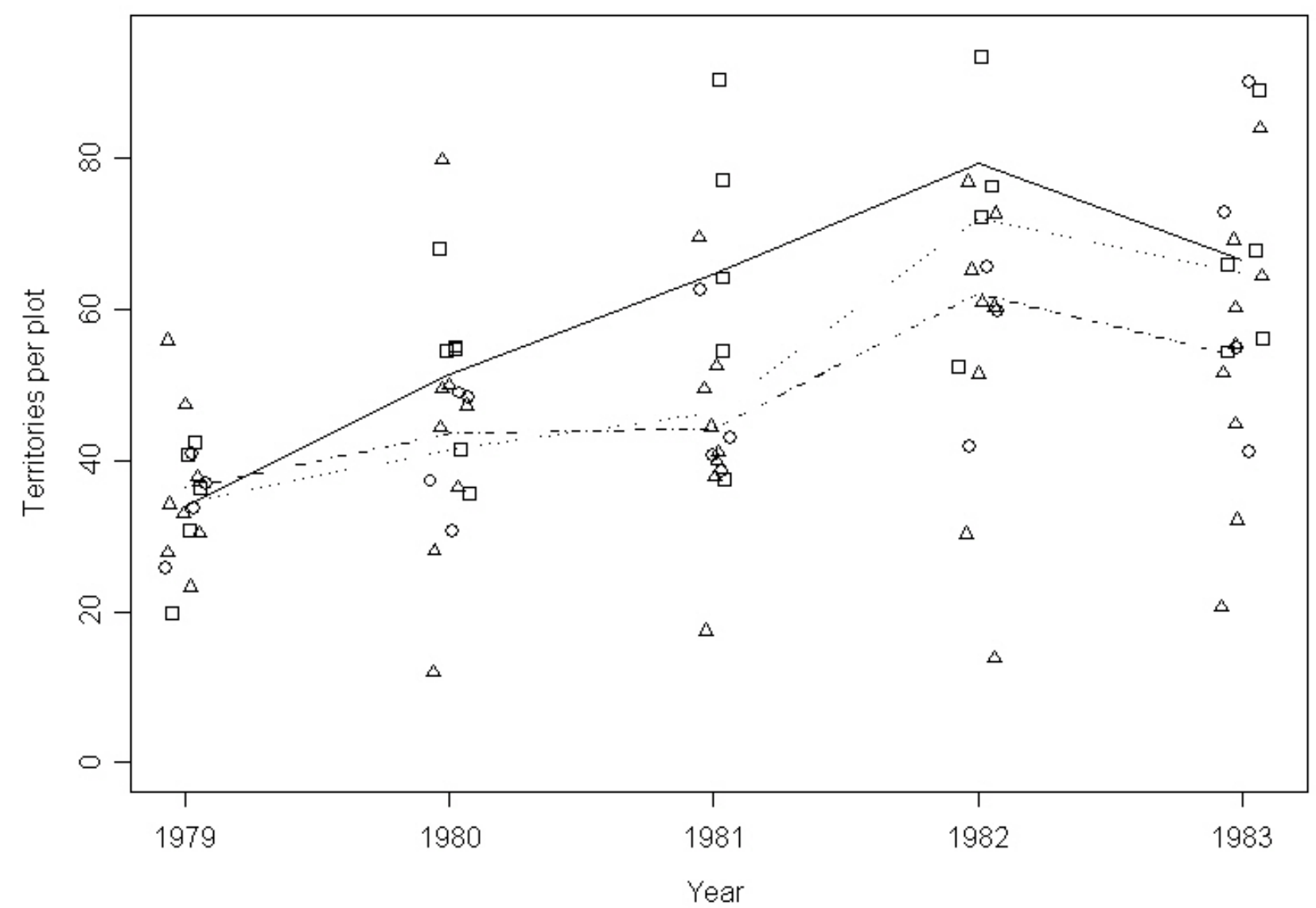

difficult to identify. Several species showed large increases in territories from $1979+1980$ to $1982+1983$ in mature plots, including the Blackburnian Warbler, which increased from 14.6 to 20.85; the Brown Creeper (Certhia americana), 4 to 8.15; the Black-throated Blue Warbler (Dendroica caerulescens), 0.35 to 3.7 ; the Blueheaded Vireo (Vireo solitarius), 3.7 to 7.75 ; the Winter Wren (Troglodytes troglodytes), 5.3 to 12.95; and the Evening Grosbeak (Coccothraustes vespertinus), 0 to 7.75 (Fig. 6).
In the young stand-age category, 147 of $231(65 \%)$ comparisons of species and stand-age category demonstrated a positive change from $1979+1980$ to $1982+1983$. In the intermediate stand-age category, 75 of $115(64 \%)$ comparisons showed positive changes, and in the mature stand-age category, 78 of $117(67 \%)$ comparisons showed positive changes. Although it is difficult to draw strong conclusions about individual species based on these analyses, it is clear that the large increase in the numbers of territories observed over the study 
Fig. 4. Number of territories of (A) Bay-breasted Warbler (Dendroica castanea), (B) Tennessee Warbler (Vermivora peregrina), and (C) Cape May Warbler (Dendroica tigrina) in young stands (triangles represent plots, dashed line represents mean), intermediate-aged stands (circles represent plots, dotted line represents mean), and mature stands (squares represent plots, solid line represents mean).
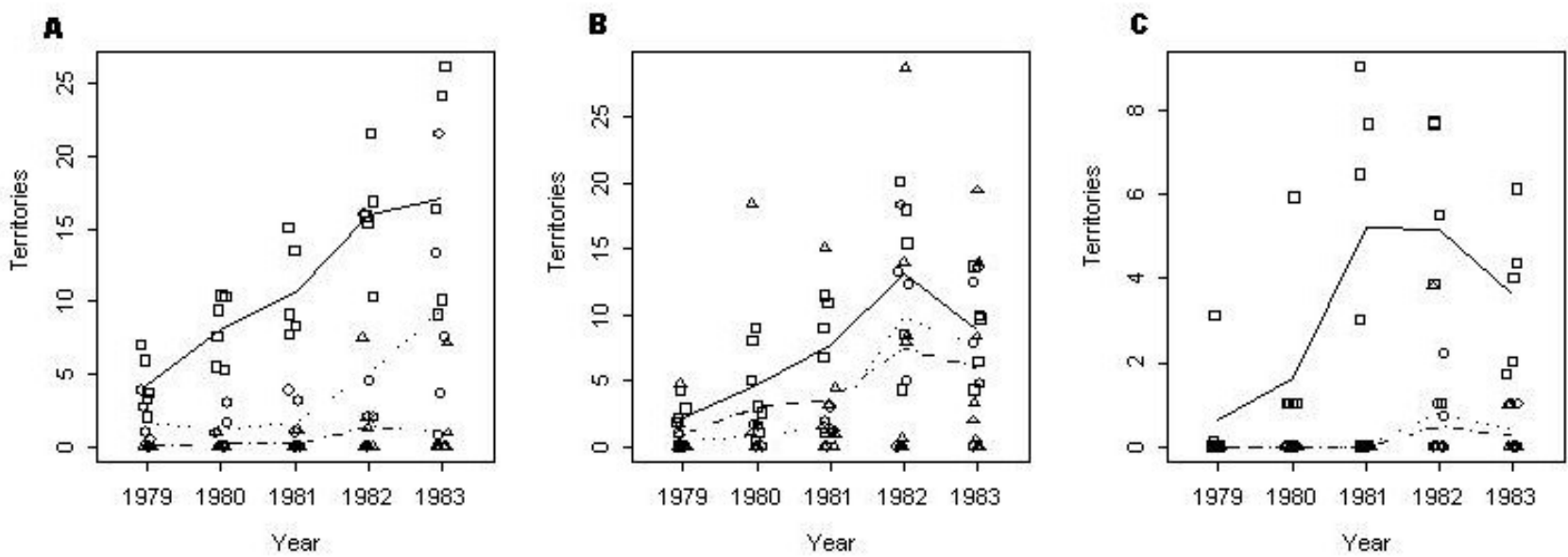

period was a consequence of a positive response by multiple species and not just a few strong responders. Although we expected that the number of territories for some species would be reduced because of competition from other increasing species, no species was notably less abundant in $1982+1983$ than in $1979+1980$ (Table 1$)$.

\section{DISCUSSION}

\section{The budworm specialists}

A wide variety of bird species has been shown to respond numerically to spruce budworm outbreaks (Appendix 1). Three species that have been consistently identified as spruce budworm specialists are the Bay-breasted Warbler, the Tennessee Warbler, and the Cape May Warbler (Kendeigh 1947, MacArthur 1958, Morris et al. 1958). For example, Bay-breasted Warblers showed a 12-fold increase over $12 \mathrm{yr}$ in the 1958 study by Morris et al. Tennessee Warblers increased from no pairs to 122 pairs/100 ha in the same study. Morse (1978) found a 12-fold increase in Cape May Warblers from 1974 to 1976 . These results are consistent with our findings, in which these species increased 4.7- to 10.4-fold or more over four years; no other species increased more than twofold over the same time period. These three species are relatively uncommon in years in which there are no budworm outbreaks (Sanders 1970). Even in this study area, in which we believe that budworm populations were already on the rise in 1979, Baybreasted Warbler, Tennessee Warbler, and Cape May Warbler moved from the ranks of 6th, 11th, and 35 th most common species that year to $2 \mathrm{nd}, 1 \mathrm{st}$, and 10th, respectively, in 1982.

It is possible that these species respond rapidly to budworm outbreaks because they are able to increase their clutch sizes in response to outbreaks (Morse 1989, Williams 1996, Baltz and Latta 1998). MacArthur (1958) observed that Bay-breasted Warbler clutches were smaller during endemic budworm levels than during epidemic levels. The clutch sizes of Bay-breasted Warblers, Tennessee Warblers, and Cape May Warblers all have larger ranges relative to those of most other wood warblers (Ehrlich et al. 1988). Even though these three species are able to consistently respond numerically to budworm outbreaks, it is unlikely that they can 
Fig. 5. Mean number of territories per plot for all species (circles, dotted line represents means), and for all species except Bay-breasted Warbler (Dendroica castanea), Tennessee Warbler (Vermivora peregrina), and Cape May Warbler (Dendroica tigrina; squares, solid line represents means).

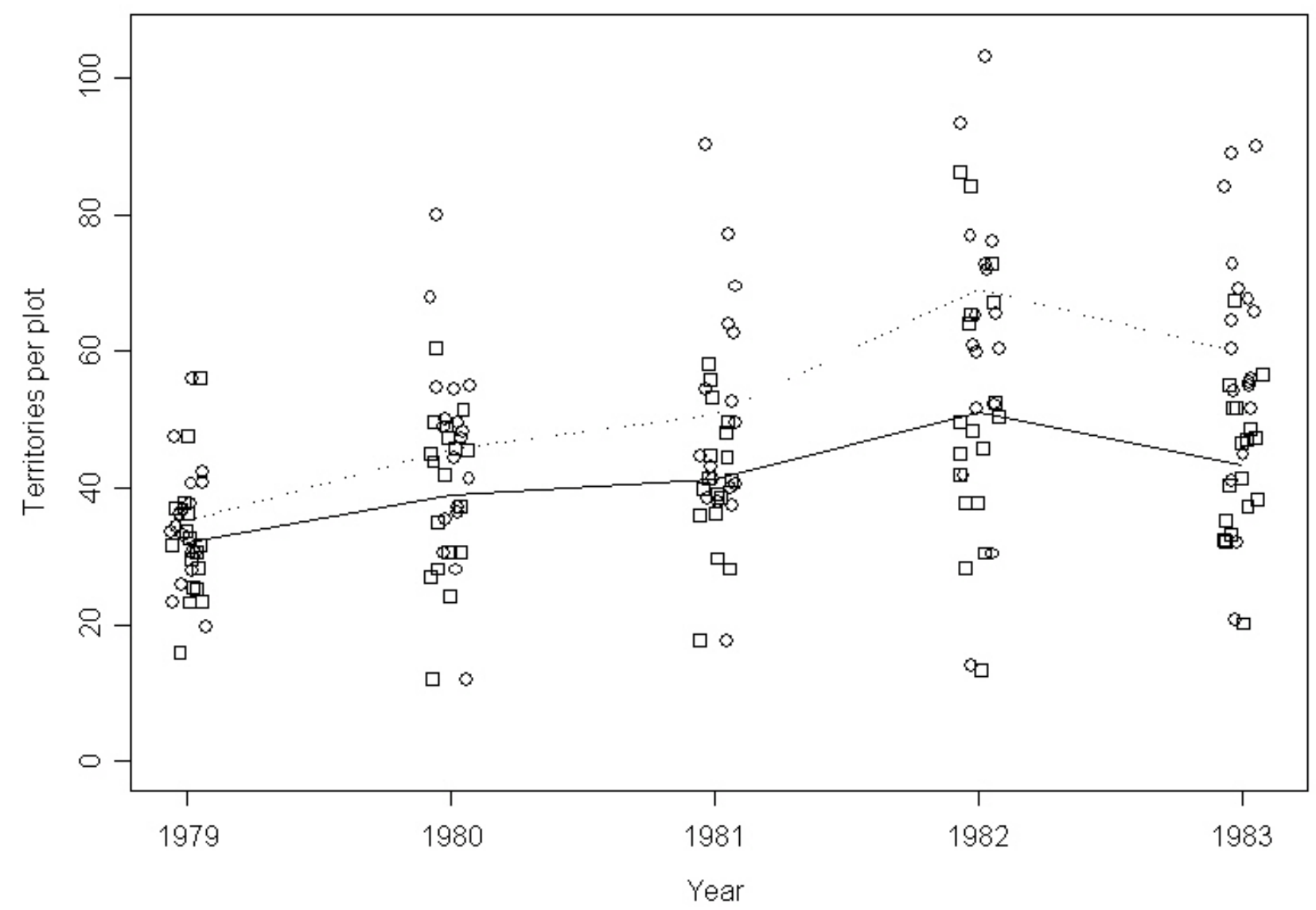

control budworm effectively. Crawford et al. (1983) note that the most important bird predators are those that maintain high population densities and high feeding rates over the lower ranges of the insect's density and found that this was most true of the Blackburnian Warbler and Golden-crowned Kinglet and not of the three budworm specialists.

Budworm defoliation in Ontario peaked in 1980 at $18,850,000$ ha and has declined steadily since then to 280,000 ha in 2004 (Cadman et al 2007). In a recent synthesis of the status and trends of birds in Ontario, Blancher et al. (2009) reviewed evidence for long-term trends in Ontario birds. Analysis of migration monitoring data from Long Point Bird Observatory indicated good evidence for population declines in all three budworm specialists from the 1981-1986 period to the 2001-2006 period. All three species showed statistically significant annual declines in spring and fall migration numbers: for Cape May Warblers, 4.4\% $(p<0.000)$ and 3.2\% ( $p$ $<0.000)$; for Bay-breasted Warblers, 3.4\% ( $p<$ 
Fig. 6. Number of territories per plot for mature plots (squares represent plots, solid line represents means), intermediate-aged plots (circles represent plots, dotted line represents means), and young plots (triangles represent plots, dashed line represents means) for 20 individual species.
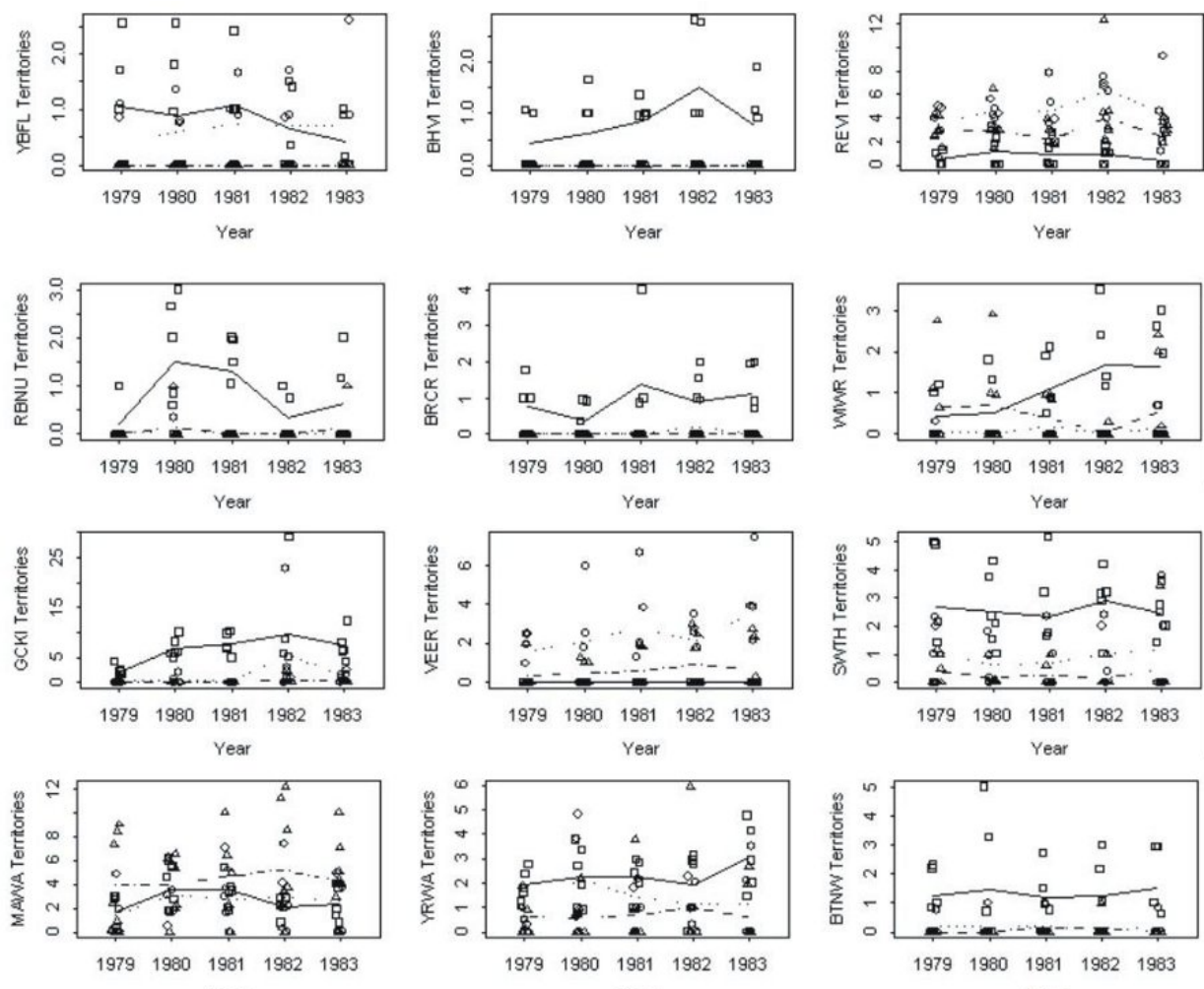

Year
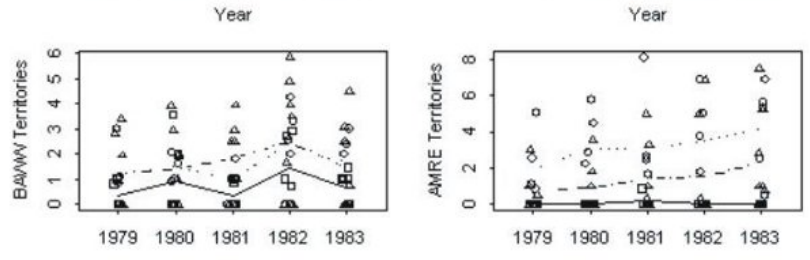

Year
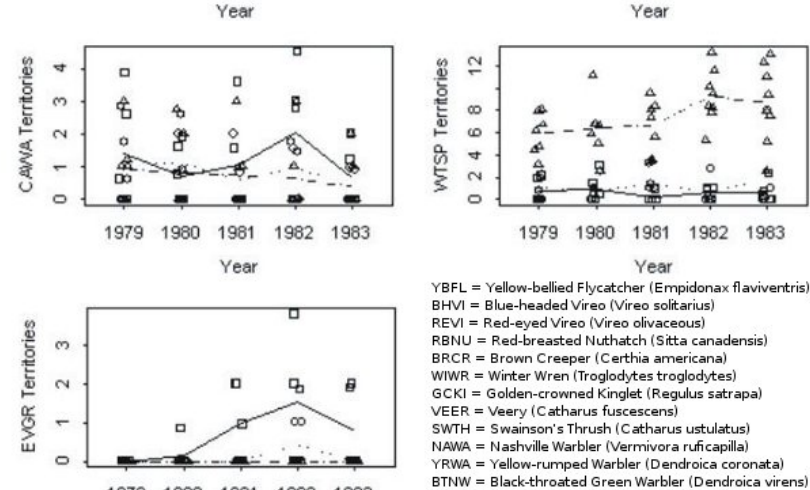

YBFL $=$ Yellow-bellied Fl, Year

YBFL $=$ Yellow-bellied Flycatcher (Empidonax flaviventris)
BHVI $=$ Blue-headed Vireo (Vireo solitarius)

REVI = Red-eyed Vireo (Vireo olivaceous)

RBNU = Redbreated

WIWR $=$ Winter Wren (Troglodytes troglodytes)

GCKI $=$ Golden-crowned Kinglet (Regulus satrapa)

VEER $=$ Veery (Catharus fuscescens)

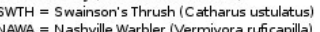

YRWA $=$ Yellowile Warber

BTNW $=$ Black-throated Green Warbler (Dendroica virens)

BLBW = Blackburnian Warbler (Dendroica fusca)

BAWW = Black-and-white Warbler (Mniotitta varia)

AMRE $=$ American Redstart (setophaga ruticil

CAWA $=$ Canada Warbler (Wilsonia canadensis) 
Table 1. Change in number of territories from $1979+1980$ to $1982+1983$, and results of Wilcoxon signedranks test for paired data for the 30 most common species in the study plots. $P$-values less than 0.05 are highlighted in gray along with their associated species. For $n>25$ or when there are ties, the normal approximation $(z)$ of the test statistic is provided, otherwise the Wilcoxon signed-ranks test statistic $V$ is provided. RUGR $=$ Ruffled Grouse $($ Bonasa umbellus), YBFL = Yellow-bellied Flycatcher $($ Empidonax flaviventris), ALFL = Alder Flycatcher (Empidonax alnorum), LEFL = Least Flycatcher (Empidonax minimus), REVI = Red-eyed Vireo (Vireo olivaceus), PHVI = Philadephia Vireo (Vireo philadelphicus), $\mathrm{BCCH}=$ Black-capped Chickadee (Poecile hudsonia), WIWR = Winter Wren (Troglodytes troglodytes), GCKI = Golden-crowned Kinglet (Regulus satrapa), VEER = Veery (Catharus fuscenscens), SWTH = Swainson's Thrush (Catharus ustulatus), HETH = Hermit Thrush (Catharus guttatus), TEWA = Tennessee Warbler (Vermivora peregrina), NAWA = Nashville Warbler (Vermivora ruficapilla), CSWA $=$ Chestnutsided Warbler (Dendroica pensylvanica), MAWA = Magnolia Warbler (Dendroica magnolia), CMWA = Cape May Warbler (Dendroica tigrina), YRWA = Yellow-rumped Warbler (Dendroica coronata), BTNW = Black-throated Green Warbler (Dendroica virens), BLBW = Blackburnian Warbler (Dendroica fusca), BBWA = Bay-breasted Warbler (Dendroica castanea), BAWW = Black-and-white Warbler (Mniotilta varia), AMRE = American Redstart (Setophaga ruticilla), OVEN = Ovenbird (Seiurus aurocapilla), MOWA = Mourning Warbler (Oporonis philadelphia), CAWA = Canada Warbler (Wilsonia canadensis), LISP = Lincoln's Sparrow (Melospiza lincolnii), WTSP = White-throated Sparrow (Zonotrichia albicollis), RBGR = Rose-breasted Grosbeak (Pheucticus ludovicianus), and PUFI = Purple Finch (Carpodacus purpureus).

\begin{tabular}{|c|c|c|c|c|c|c|c|c|c|c|c|c|}
\hline \multirow[t]{2}{*}{ Species } & \multicolumn{3}{|c|}{ Plots of all ages } & \multicolumn{3}{|c|}{ Youngs plots } & \multicolumn{3}{|c|}{$\begin{array}{c}\text { Mature and } \\
\text { intermediate plots }\end{array}$} & \multicolumn{3}{|c|}{$\begin{array}{l}\text { Intermediate and } \\
\text { young plots }\end{array}$} \\
\hline & Change & $z$ & $p$ & Change & $z(V)$ & $p$ & Change & $z(V)$ & $p$ & Change & $z(V)$ & $p$ \\
\hline RUGR & -3.95 & 0.52 & 0.6031 & -6.35 & 1.8454 & 0.0650 & 2.4 & -0.8422 & 0.3997 & -1.65 & 0.3944 & 0.693 \\
\hline YBFL & -3.75 & 0.977 & 0.3286 & -0.75 & 0.875 & 0.3816 & -3 & 0.5671 & 0.5706 & 2.1 & -0.1421 & 0.887 \\
\hline ALFL & 18.7 & -0.4173 & 0.6765 & 18.7 & (10) & 0.3125 & & NA & NA & 18.7 & -0.6024 & 0.547 \\
\hline LEFL & 15.35 & -0.738 & 0.4608 & -3.05 & 0.2836 & 0.7768 & 18.4 & -1.233 & 0.2175 & 15.15 & -0.5512 & 0.582 \\
\hline REVI & 22.1 & -1.009 & 0.3131 & 13 & (14) & 0.6406 & 9.1 & -0.773 & 0.4395 & 22.8 & -1.2556 & 0.209 \\
\hline PHVI & 13.15 & -1.5476 & 0.1217 & 3 & -1.5255 & 0.1271 & 10.15 & -0.798 & 0.4249 & 11.15 & -1.808 & 0.071 \\
\hline $\mathrm{BCCH}$ & 12.75 & -1.0973 & 0.2725 & 5.65 & 0.1418 & 0.8873 & 7.1 & -1.6325 & 0.1026 & 10.85 & -0.4363 & 0.663 \\
\hline WIWR & 3.6 & -0.3688 & 0.7123 & -3.75 & 0.7019 & 0.4828 & 7.35 & -1.1371 & 0.2555 & -4.05 & 0.8434 & 0.399 \\
\hline GCKI & 44.15 & -2.308 & 0.021 & 4.1 & -1.317 & 0.1878 & 40.05 & -1.8248 & 0.0680 & 33.6 & -2.1698 & 0.03 \\
\hline VEER & 17.15 & -2.1422 & 0.0322 & 7.35 & -0.9855 & 0.3244 & 9.8 & -1.8952 & 0.0581 & 17.15 & -2.1285 & 0.033 \\
\hline SWTH & 4.55 & 0.1306 & 0.8961 & -2.55 & 0.8339 & 0.4043 & 7.1 & (14) & 0.6406 & 3.1 & -0.2008 & 0.841 \\
\hline HETH & 5.25 & -1.2647 & 0.206 & 3.15 & -1.1356 & 0.2561 & 2.1 & -0.3627 & 0.7168 & 6 & -1.3393 & 0.181 \\
\hline TEWA & 219.35 & -3.14 & 0.0017 & 102.95 & -1.8843 & 0.0653 & 116.4 & -2.3863 & 0.017 & 160.45 & -2.4981 & 0.013 \\
\hline NAWA & 8.2 & -0.6476 & 0.5173 & 13.7 & (6) & 0.1094 & -5.5 & 1.1342 & 0.2567 & 6.4 & -0.3139 & 0.754 \\
\hline CSWA & 23.15 & -0.601 & 0.548 & 25.35 & (13) & 0.5469 & -2.2 & 0.0758 & 0.9396 & 23.1 & -0.5495 & 0.583 \\
\hline
\end{tabular}




\begin{tabular}{|c|c|c|c|c|c|c|c|c|c|c|c|c|}
\hline MAWA & 21.55 & -1.19 & 0.234 & 19.85 & -1.6845 & 0.0921 & 1.7 & (18) & 1 & 23.45 & -1.6486 & 0.099 \\
\hline CMWA & 44.45 & -2.9057 & 0.0037 & 7.8 & -1.6385 & 0.1013 & 36.65 & -2.2684 & 0.0233 & 11.7 & -2.1698 & 0.03 \\
\hline YRWA & 4.95 & -0.1036 & 0.9175 & 6.05 & -0.4253 & 0.6706 & -1.1 & (24) & 0.4609 & 3.25 & 0.1575 & 0.875 \\
\hline BTNW & -1.25 & -0.3496 & 0.7266 & 1 & -0.875 & 0.3816 & -2.25 & 0.0758 & 0.9396 & 0.1 & & 1 \\
\hline BLBW & 6.25 & -1.0658 & 0.2865 & & NA & NA & 6.25 & -1.1371 & 0.2555 & & NA & NA \\
\hline BBWA & 162.1 & -3.35 & 0.0008 & 23.85 & -2.1039 & 0.0354 & 138.25 & (0) & 0.0078 & 75.6 & -2.8153 & 0.005 \\
\hline BAWW & 22.6 & -2.9528 & 0.0031 & 14.75 & -2.3863 & 0.017 & 7.85 & -1.4037 & 0.1604 & 20.9 & -2.7477 & 0.006 \\
\hline AMRE & 33 & -2.134 & 0.0328 & 20.05 & -1.5595 & 0.1189 & 12.95 & -1.1371 & 0.2555 & 33 & -2.205 & 0.028 \\
\hline OVEN & 27.55 & -1.9066 & 0.0566 & 2.9 & -0.8339 & 0.4043 & 24.65 & (5) & 0.0781 & 25 & -2.1285 & 0.033 \\
\hline MOWA & -1.7 & 0.0261 & 0.9792 & -2.25 & (20) & 0.8438 & 0.55 & & 1 & -1.7 & (40) & 0.97 \\
\hline CAWA & -5.65 & 0.5006 & 0.6166 & -3.75 & 0.5811 & 0.5611 & -1.9 & 0.1418 & 0.8873 & -7.85 & 1.0446 & 0.296 \\
\hline LISP & 0.05 & 0.66 & 0.5092 & 0.05 & 0.4253 & 0.6706 & & NA & NA & 0.05 & 0.5921 & 0.554 \\
\hline WTSP & 49.35 & -2.28 & 0.0228 & 50.2 & -2.4535 & 0.0141 & -0.85 & 0.2807 & 0.7789 & 47.75 & -2.2776 & 0.023 \\
\hline RBGR & 2.85 & -0.3448 & 0.7302 & 4.55 & & 1 & -1.7 & & 1 & 1.95 & & 1 \\
\hline PUFI & 8.8 & -2.0619 & 0.0392 & 4.2 & -1.8667 & 0.0619 & 4.6 & -0.798 & 0.4249 & 5.15 & -1.822 & 0.685 \\
\hline
\end{tabular}

$0.000)$ and $6.0 \%(p<0.000)$; and for Tennessee Warblers, 5.6\% $(p<0.000)$ and 3.2\% $(p<0.000)$, respectively. Results here and elsewhere suggest that population levels of spruce budworm may have an important effect on the population levels of these three species. Consequently, the status of spruce budworm should be considered when monitoring and interpreting the status of these budworm specialists. Similarly, factors that may alter the severity and extent of spruce budworm outbreaks, such as climate change, changing forest composition because of forestry, the suppression of forest fires, and the active suppression of budworm with insecticides such as Bt (Bacillus thuringiensis), have the potential to alter the long-term fate of spruce budworm bird specialists.

Our results confirmed the status of the Cape May Warbler, Tennessee Warbler, and Bay-breasted Warbler as budworm specialists. Each species showed a dramatic numerical response in all three stand-age classes, their habitat choices became more generalized with increasing abundance of budworm, and their responses were notably larger than those of any other species. Although Baybreasted Warbler and Cape May Warbler are considered mature-forest species (Williams 1996,
Baltz and Latta 1998), they clearly alter their habitat choices in the face of superabundant food. Cape May Warblers, which sing, feed, and nest high in the spruce canopy (Baltz and Latta 1998), did not occur in the young and intermediate plots in 19791981 but increased dramatically in numbers in these plots later in the spruce budworm outbreak. Baybreasted Warblers tell a similar story, with relatively low territory numbers in 1979-1981 in the young and intermediate plots and significant increases in 1982 and 1983, with higher territory numbers than were present in mature plots in 1979. The response of these species in young and intermediate stands differed in mature stands. In younger stands, the response came later in the outbreak progression, although proportionally the response was as strong or stronger. Budworm density was higher in older stands and increased from 1982 to 1983 in all three stand-age categories. New territories were still being established in mature and younger stands in 1982 and 1983, suggesting that the younger stands were improving in their capacity to provide desirable habitat for individuals, and not that individuals were moving from mature habitat to younger habitat because mature habitat was becoming less suitable. 
Although Tennessee Warblers are known to use a wide range of habitat ages (Rimmer and McFarland 1998), they showed a clear preference for mature plots in our study area. Their response was slower in the younger plots than in the mature plots but more immediate than those of the other two species. They also showed a proportionally higher response in the younger plots than did Bay-breasted Warbler and Cape May Warbler.

\section{Budworm-bird interactions}

Overall, birds had a positive numerical response to the spruce budworm outbreak; numbers of birds and species increased through time, and the total number of individuals was positively related to budworm density in 1982 and 1983. The decline in total number of individuals and species in 1983 suggests that a significant event affected bird abundance in that year. Because we do not have good quantitative information on the change in spruce budworm abundance throughout the study period, we cannot reliably relate these changes in bird abundance to spruce budworm density. However, it was observed that the budworm outbreak increased in intensity throughout the 5-yr study period (D. R. Fillman, unpublished data). Budworm counts from 1982 and 1983 are consistent with this position, but, it is unclear if the total abundance of budworm available for bird foraging was greater in 1983 than 1982 because we have no measures of the total foliage available for foraging. It is possible that there were fewer spruce budworm available for foraging by 1983. Alternatively, an abiotic factor such as a weather event may have reduced territory numbers. We examined the annual weather data for the period of the study and found no anomalies in the 1983 breeding season relative to long-term normals.

An overall increase in number of territories for all species combined, even when the three budworm specialists were excluded, suggests that many, if not most, species enjoyed a positive benefit from the budworm outbreak. Many of the species considered here reportedly consume budworm (Mitchell 1952, Dowden et al. 1953, Crawford and Jennings 1989). Although we cannot demonstrate a statistically significant numerical response for individual species because of the large number of comparisons made, positive responses in the young and intermediate stand-age categories are suggested for Golden-crowned Kinglet, Veery, Black-and-white Warbler, American Redstart, Ovenbird, White- throated Sparrow, and Purple Finch. Positive responses in the mature stand-age category include Blackburnian Warbler, Brown Creeper, Blackthroated Blue Warbler, Blue-headed Vireo, Winter Wren, and Evening Grosbeak. Of the 13 species with positive responses, seven showed positive responses in at least one previous study. No response has been reported previously for five species: Brown Creeper, Veery, Black-throated Blue Warbler, Black-and-white Warbler, and American Redstart. One species, Winter Wren, had previously shown only a negative response to budworm (Appendix 1).

We did not find a decline in abundance through the study period for any species. Magnolia Warbler (Dendroica magnolia), Black-throated Green Warbler (Dendroica virens), Blackburnian Warbler, Yellow-rumped Warbler, and Winter Wren have all reportedly had negative responses to spurce budworm elsewhere, which were attributed to competition with increasing species (Appendix 1). Based on stomach content analysis, all five of these species appear to eat budworm (Mitchell 1952, Dowden et al. 1953, Crawford and Jennings 1989). We found some evidence for a positive response in Blackburnian Warbler and Winter Wren and possibly Magnolia Warbler (Table 1), but no evidence of a response in Black-throated Green Warbler or Yellow-rumped Warbler. In most cases, the evidence in the literature for competition comes from one or only a few locations and may not describe a general response to budworm or a response to budworm at all. Conditions specific to each location and time may play enough of a role in the response of species that it is difficult to generalize based on only a few observations.

\section{CONCLUSION}

Spruce budworm exert a major influence on the boreal ecosystems of eastern Canada (Blais 1983, Candau et al. 1998) by causing tree mortality over large areas. The last outbreak in eastern Canada resulted in the defoliation of more than 55 million ha of forest (Blais 1983). Budworm outbreaks also have a direct effect on forest bird populations by providing superabundant food for many species. Our data suggest that many bird species profit from the increased abundance of food, but only three species, specifically the Bay-breasted Warbler, the Tennessee Warbler, and the Cape May Warbler, respond with large population increases of up to 
tenfold over four to five years. These species appear to alter their usual habitat selection by establishing their territories in young and intermediate-aged stands as budworm numbers increase. Although the number of territories in young and intermediateaged stands grew more slowly in response to the outbreaks, there were still very important increases in bird numbers with higher budworm counts. Contrary to some previous studies, we found no species with a negative numerical response. The cyclical nature of budworm outbreaks makes it difficult to assess the status of populations of the three specialists unless these outbreaks are taken into consideration. These outbreaks may also be important in the long-term population trajectories of nonspecialist species.

Responses to this article can be read online at: http://www.ace-eco.org/vol4/iss 1/art3/responses/

\section{Acknowledgments:}

This paper is dedicated to the memory of Dan Welsh, a passionate ecologist and a great friend. Field data were collected by Frank Brazzo, Barb Campbell, Simon Gawn, Mark Gawn, Bob Gorman, Eva Laubitz, Ann Macauley, S. O’Donnell, Miriam Oudejans, Ed Poroprt, Carrie Spencer, Belinda Watson, andAlec White. Thanks to Peter Martindale and the Ontario Ministry of Natural Resources for logistic support, food, and lodging and to Pia Papadopal, Kerrie Wainio-Keizer, and Ron Fournier for logistic support. Steve Holmes and Kim Chapman provided helpful comments on the manuscript.

\section{LITERATURE CITED}

Baltz, M. E., and S. C. Latta. 1998. Cape May Warbler (Dendroica tigrina). Birds of North America, No. 332. Academy of Natural Sciences, Philadelphia, Pennsylvania, USA, and American Ornithologists' Union, Washington, D.C., USA.

Bergeron, Y., A. Leduc, H. Morin, and C. Joyal. 1995. Balsam fir mortality following the last spruce budworm outbreak in north-western Quebec. Canadian Journal of Forest Research 25:1375-1384.
Blais, J. R. 1983. Trends in the frequency, extent, and severity of spruce budworm outbreaks in eastern Canada. Canadian Journal of Forest Research 13:539-547.

Blais, J. R., and G. H. Parks. 1964. Interaction of evening grosbeak (Hesperiphona vespertina) and spruce budworm (Choristoneura fumiferana (Clem.)) in a localized budworm outbreak treated with DDT in Quebec. Canadian Journal of Zoology 42:1017-1024.

Blancher, P. J., R. D. Phoenix, D. S. Badzinski, M. D. Cadman, T. L. Crewe, C. M. Downes, D. Fillman, C. M. Francis, J. Hughes, D. J. T. Hussell, D. Lepage, J. D. McCracken, D. K. McNicol, B. A. Pond, R. K. Ross, R. Russell, L. A. Venier, and R. C. Weeber. 2009. Population trend status of Ontario's forest birds. Forestry Chronicle 85:184-201. Available online at: http://w ww.cif-ifc.org/uploads//Website Assets/Blancher et al. pdf.

Bolgiano, N. C. 2004. Cause and effect: changes in boreal bird irruptions in eastern North America relative to the 1970 s spruce budworm infestation. American Birds 58:26-33.

Cadman, M. D., D. A. Sutherland, G. G. Beck, D. LePage, and A. R. Couturier. 2007. Atlas of the breeding birds of Ontario, 2001-2005. Bird Studies Canada, Environment Canada, Ontario Field Ornithologists, Ontario Ministry of Natural Resources, and Ontario Nature, Toronto, Ontario, Canada.

Canadian Biodiversity Strategy. 1995. Canadian biodiversity strategy: Canada's response to the Convention on Biological Diversity. Minister of Supply and Services Canada, Ottawa, Ontario, Canada. Available online at: http://www.cbin.ec.gc. ca/documents/national reports/cbs e.pdf.

Candau, J.-N., and R. A. Fleming. 2005. Landscape-scale spatial distribution of spruce budworm defoliation in relation to bioclimatic conditions. Canadian Journal of Forest Research 35:2218-2232.

Candau, J.-N., R. A. Fleming, and A. Hopkin. 1998. Spatiotemporal patterns of large-scale defoliation caused by the spruce budworm in Ontario since 1941. Canadian Journal of Forest Research 28:1733- 1741. 
Crawford, H. S., and D. T. Jennings. 1989. Predation by birds on spruce budworm Choristoneura fumiferana: functional, numerical, and total responses. Ecology 70:152-163.

Crawford, H. S., R. W. Titterington, and D. T. Jennings. 1983. Bird predation and spruce budworm populations. Journal of Forestry 81:433-435.

Dowden, P. B., H. A. Jaynes, and V. M. Carolin. 1953. The role of birds in a spruce budworm outbreak in Maine. Journal of Economic Entomology 46:307-312.

Ehrlich, P. R., D. S. Dobkin, and D. Wheye. 1988. The birder's handbook: a field guide to the natural history of North American birds. Simon and Schuster, New York, New York, USA.

Erskine, A. J. 1977. Birds in boreal Canada: communities, densities and adaptations. Canadian Wildlife Service Report Series, No. 41. Fisheries and Environment Canada, Ottawa, Ontario, Canada.

Gage, S. H., and C. A. Miller. 1978. A long term bird census in spruce budworm-prone balsam fir habitats in northwestern New Brunswick. Information Report M-X-84. Department of Fisheries and the Environment, Canadian Forestry Service, Maritimes Forest Research Centre, Fredericton, New Brunswick, Canada.

Helle, P., and M. Mönkkönen. 1990. Forest successions and bird communities: theoretical aspects and practical implications. Pages 229-318 in A. Keast, editor. Biogeography and ecology of forest bird communities. SPB Academic, The Hague, The Netherlands.

Hensley, M. M., and J. B. Cope. 1951. Further data on removal and repopulation of the breeding birds in a spruce-fir forest community. The Auk 68:483-493.

Hobson, K. A., and J. Schieck. 1999. Changes in bird communities in boreal mixedwood forest: harvest and wildfire effects over 30 years. Ecological Applications 9:849-863.

Holloway, G. L., B. J. Naylor, and W. R. Watt. 2004. Habitat relationships of wildlife in Ontario: revised habitat suitability models for the Great
Lakes-St. Lawrence and boreal east forest. Southern Science and Information and Northeast Science and Information Joint Technical Report Number 1. Ontario Ministry of Natural Resources, Toronto, Ontario, Canada.

International Bird Census Committee (IBCC). 1970. An international standard for a mapping method in bird census work. Bird Study 16:248-255.

Kendeigh, S. C. 1947. Bird population studies in the coniferous forest biome during a spruce budworm outbreak. Ontario Department of Lands and Forests Biological Bulletin Number 1. Ontario Department of Lands and Forests, Toronto, Ontario, Canada.

MacArthur, R. H. 1958. Population ecology of some warblers of northeastern coniferous forests. Ecology 39:599-619.

MacLean, D. A., and A. R. Andersen. 2008. Impact of a spruce budworm outbreak in balsam fir and subsequent stand development over a 40-year period. Forestry Chronicle 84:60-69.

Mitchell, R. 1952. Consumption of spruce budworms by birds in a Maine spruce-fir forest. Journal of Forestry 50:387-389.

Morris, R. F. 1955. The development of sampling techniques for forest insect defoliators, with particular reference to the spruce budworm. Canadian Journal of Zoology 33:225-294.

Morris, R. F., W. F. Cheshire, C. A. Miller, and D. G. Mott. 1958. The numerical response of avian and mammalian predators during a gradation of the spruce budworm. Ecology 39:487-494.

Morse, D. H. 1978. Populations of Bay-breasted and Cape May warblers during an outbreak of the spruce budworm. Wilson Bulletin 90:404-413.

Morse, D. H. 1989. American warblers: an ecological and behavioral perspective. Harvard University Press, Cambridge, Massachusetts, USA.

Niemi, G., J. Hanowski, P. Helle, R. Howe, M. Mönkkönen, L. Venier, and D. Welsh. 1998. Ecological sustainability of birds in boreal systems. Conservation Ecology 2(2):17 [online] URL: http:/ /www.consecol.org/vol2/iss2/art17/. 
Ontario Ministry of Natural Resources. 2005. Protecting what sustains us: Ontario's biodiversity strategy. Ontario Ministry of Natural Resources, Toronto, Ontario, Canada. Available online at: http ://www.mnr.gov.on.ca/MNR E000066.pdf.

Ontario Partners in Flight. 2006. Ontario Landbird Conservation Plan: boreal softwood shield (North American Bird Conservation Region 8); priorities, objectives and recommended actions. Environment Canada, Ottawa, and Ontario Ministry of Natural Resources, Toronto, Ontario, Canada. Available online at: http://www.bsc-eoc.org/PIF/PI FOBCR8planMay2006.pdf.

Patten, M. A., and J. C. Burger. 1998. Spruce budworm outbreaks and the incidence of vagrancy in eastern North American wood-warblers. Canadian Journal of Zoology 76:433-439.

Rimmer, C. C., and K. P. McFarland. 1998. Tennessee Warbler (Vermivora peregrina). Birds of North America, No. 350. Academy of Natural Sciences, Philadelphia, Pennsylvania, USA, and American Ornithologists' Union, Washington, D. C., USA.

Rowe, J. S. 1972. Forest regions of Canada. Canadian Forestry Services Publication No. 1300. Department of the Environment, Ottawa, Ontario, Canada.

Sanders, C. J. 1970. Populations of breeding birds in the spruce-fir forests of northwestern Ontario. Canadian Field Naturalists 84:131-135.

Stewart, R. E., and J. W.Aldrich. 1952. Ecological studies of breeding bird populations in northern Maine. Ecology 33:226-238.

Venier, L. A., and J. L. Pearce. 2004. Birds as indicators of sustainable forest management. Forestry Chronicle 80:61-66.

Venier, L. A., and J. L. Pearce. 2005. Boreal bird community response to jack pine forest succession. Forest Ecology and Management 217:19-36.

Venier, L. A., J. L. Pearce, B. A. Wintle, and S. A. Bekessy. 2007. Future forests and indicatorspecies population models. Forestry Chronicle 83:36-40.

Voigt, D. R., J. A. Baker, R. S. Rempel, and I. D.
Thompson. 2000. Forest vertebrate responses to landscape-level changes in Ontario. Pages 198-233 in A. H. Perera, D. L. Euler, and I. D. Thompson, editors. Ecology of a managed terrestrial landscape: patterns and processes in forest landscapes of Ontario. University of British Columbia Press, Vancouver, British Columbia, USA.

Welsh, D. A. 1985. Preliminary studies of the relation between spruce budworm and birds in the boreal forest of Ontario. Pages 100-101 in C. J. Sanders, R. W. Stark, E. J. Mullins, and J. Murphy, editors. Recent advances in spruce budworm research: proceedings of the CANUSA Spruce Budworm Research Symposium. Canadian Forest Service, Ottawa, Ontario, Canada.

Welsh, D. A. 1987. The influence of forest harvesting on mixed coniferous-deciduous boreal bird communities in Ontario, Canada. Acta Oecologica 8:247-252.

Williams, J. M. 1996. Bay-breasted Warbler (Dendroica castanea). Birds of North America, No. 206. Academy of Natural Sciences, Philadelphia, Pennsylvania, USA, and American Ornithologists' Union, Washington, D.C., USA.

Zach, R., and J. B. Falls. 1975. Response of the ovenbird (Aves: Paulidae) to an outbreak of the spruce budworm. Canadian Journal of Zoology 53:1669-1672.

Zar, J. H. 1984. Biostatistical analysis. Second edition. Prentice-Hall, Englewood Cliffs, New Jersey, USA. 


\section{APPENDIX 1}

Table A1-1. Summary of species response to spruce budworm (Choristoneura fumiferana (Clem.)) from the literature. A numerical response indicates a change in the number of individuals in conjunction with a change in budworm abundance. A functional response indicates a change in behavior in conjunction with a change in budworm abundance.

\begin{tabular}{|c|c|c|c|}
\hline Species name & Response & $\begin{array}{l}\text { Budworm } \\
\text { status }\end{array}$ & References \\
\hline $\begin{array}{l}\text { Yellow-bellied Flycatcher } \\
\text { (Empidonax flaviventris) }\end{array}$ & $\begin{array}{l}\text { Positive numerical } \\
\text { None } \\
\text { None }\end{array}$ & $\begin{array}{l}\text { Epidemic } \\
\text { Epidemic } \\
\text { Moderate }\end{array}$ & $\begin{array}{l}\text { Gage and Miller (1978) } \\
\text { Kendeigh (1947) } \\
\text { Morris et al. (1958) } \\
\text { Hensley and Cope (1951) }\end{array}$ \\
\hline $\begin{array}{l}\text { Blue-headed Vireo } \\
\text { (Vireo solitarius) }\end{array}$ & $\begin{array}{l}\text { Positive functional } \\
\text { Positive numerical } \\
\text { None } \\
\text { None }\end{array}$ & $\begin{array}{l}\text { Moderate } \\
\text { Epidemic } \\
\text { Moderate } \\
\text { Epidemic }\end{array}$ & $\begin{array}{l}\text { Crawford and Jennings (1989) } \\
\text { Gage and Miller (1978) } \\
\text { Hensley and Cope (1951) } \\
\text { Kendeigh (1947) } \\
\text { Morris et al. (1958) }\end{array}$ \\
\hline $\begin{array}{l}\text { Red-breasted Nuthatch } \\
\text { (Sitta canadensis) }\end{array}$ & $\begin{array}{l}\text { Positive functional } \\
\text { None }\end{array}$ & $\begin{array}{l}\text { Moderate } \\
\text { Epidemic }\end{array}$ & $\begin{array}{l}\text { Crawford and Jennings (1989) } \\
\text { Morris et al. (1958) }\end{array}$ \\
\hline $\begin{array}{l}\text { Winter Wren } \\
\text { (Troglodytes troglodytes) }\end{array}$ & Negative numerical & Epidemic & Morris et al. (1958) \\
\hline $\begin{array}{l}\text { Golden-crowned Kinglet } \\
\text { (Regulus satrapa) }\end{array}$ & $\begin{array}{l}\text { Positive numerical } \\
\text { Positive numerical } \\
\text { None }\end{array}$ & $\begin{array}{l}\text { Epidemic } \\
\text { Moderate } \\
\text { Epidemic }\end{array}$ & $\begin{array}{l}\text { Morse (1978) } \\
\text { Crawford and Jennings (1989) } \\
\text { Morris et al. (1958) }\end{array}$ \\
\hline $\begin{array}{l}\text { Ruby-crowned Kinglet } \\
\text { (Regulus calendula) }\end{array}$ & $\begin{array}{l}\text { Positive functional } \\
\text { None }\end{array}$ & $\begin{array}{l}\text { Epidemic } \\
\text { Epidemic }\end{array}$ & $\begin{array}{l}\text { Crawford et al. (1983) } \\
\text { Morris et al. (1958) }\end{array}$ \\
\hline $\begin{array}{l}\text { Swainson's Thrush } \\
\text { (Catharus ustulatus) }\end{array}$ & Positive numerical & Moderate & $\begin{array}{l}\text { Morris et al. (1958) } \\
\text { Morse (1978) } \\
\text { Gage and Miller (1978) } \\
\text { Dowden et al. (1953) } \\
\text { Hensley and Cope (1951) }\end{array}$ \\
\hline $\begin{array}{l}\text { Tennessee Warbler } \\
\text { (Vermivora peregrina) }\end{array}$ & Positive numerical & Epidemic & $\begin{array}{l}\text { Morris et al. (1958) } \\
\text { Kendeigh (1947) } \\
\text { Sanders (1970) } \\
\text { Crawford et al. (1983) } \\
\text { Bolgiano (2004) } \\
\text { Gage and Miller (1978) } \\
\text { Stewart and Aldrich (1952) }\end{array}$ \\
\hline
\end{tabular}


Magnolia Warbler

(Dendroica magnolia)

Cape May Warbler

(Dendroica tigrina)

Yellow-rumped Warbler (Dendroica coronata)

Black-throated Green Warbler (Dendroica virens)

Blackburnian Warbler (Dendroica fusca)

Bay-breasted Warbler

(Dendroica castanea)

Blackpoll Warbler (Dendroica striata)

Ovenbird

(Sieurus aurocapillus)
Negative numerical Negative numerical

Positive numerical

Positive numerical None

Positive numerical Positive numerical Negative numerical

Negative numerical Positive numerical

Positive numerical

Positive numerical Negative numerical

Positive numerical

Positive numerical None

Positive numerical

Positive numerical Positive functional
Moderate Epidemic

Moderate

Epidemic Epidemic

Epidemic Moderate

Epidemic Moderate Epidemic

Epidemic

Epidemic

Moderate Epidemic

Epidemic

Epidemic

Moderate Moderate
Morris et al. (1958)

Dowden et al. (1953)

Hensley and Cope (1951) (same data)

Kendeigh (1947)

Sanders (1970)

Crawford et al. (1983)

Bolgiano (2004)

Morse (1978)

Stewart and Aldrich (1952)

Morris et al. (1958)

Gage and Miller (1978)

Gage and Miller (1978)

Stewart and Aldrich (1952)

Morris et al. (1958)

Morris et al. (1958)

Gage and Miller (1978)

Morris et al. (1958)

Sanders (1970)

Morse (1978)

Gage and Miller (1978)

Stewart and Aldrich (1952)

Morris et al. (1958)

Morris et al. (1958)

Kendeigh (1947)

Sanders (1970)

Crawford et al. (1983)

Bolgiano (2004)

Morse (1978)

Gage and Miller (1978)

Stewart and Aldrich (1952)

Bolgiano (2004)

Morris et al. (1958)

Morris et al. (1958)

Morse (1978)

Zach and Falls (1975)

Zach and Falls (1975) 
Canada Warbler

(Wilsonia canadensis)

White-throated Sparrow

(Zonotrichia albicollis)

Dark-eyed Junco

(Junco hyemalis)

Purple Finch

(Carpodacus purpureus)

Evening Grosbeak

(Coccothraustas vespertinus)
Positive numerical

Positive numerical None

Positive numerical

None

Positive numerical

None

Positive numerical

Positive numerical

None
Moderate

Epidemic

Epidemic

Epidemic

Epidemic

Epidemic

Epidemic

Epidemic

Moderate

Epidemic
Crawford and Jennings (1989)

Kendeigh (1947)

Morris et al. (1958)

Morse (1978)

Gage and Miller (1978)

Morris et al. (1958)

Bolgiano (2004)

Morris et al. (1958)

Morris et al. (1958)

Bolgiano (2004)

Blais and Parks (1964)

Crawford et al. (1983)

Gage and Miller (1978) 


\section{APPENDIX 2}

Table A2-1. Species list, total territory count, and territory density for each age group.

\begin{tabular}{|c|c|c|c|c|}
\hline Species name & $\begin{array}{l}\text { Total } \\
\text { territories }\end{array}$ & $\begin{array}{l}\text { Territories/ } \\
\text { mature plot }\end{array}$ & $\begin{array}{c}\text { Territories/ } \\
\text { intermediate plot }\end{array}$ & $\begin{array}{l}\text { Territories/ } \\
\text { young plot }\end{array}$ \\
\hline $\begin{array}{l}\text { Ruffed Grouse } \\
\text { (Bonasa umbellus) }\end{array}$ & 88.05 & 0.694 & 1.715 & 0.850 \\
\hline $\begin{array}{l}\text { Spruce Grouse } \\
\text { (Falcipennis canadensis) }\end{array}$ & 0.00 & 0.000 & 1.000 & 0.024 \\
\hline $\begin{array}{l}\text { Sharp-shinned Hawk } \\
\text { (Accipiter striatus) }\end{array}$ & 2.80 & 0.038 & 0.000 & 0.043 \\
\hline $\begin{array}{l}\text { Cooper's Hawk } \\
\text { (Accipiter cooperii) }\end{array}$ & 1.00 & 0.000 & 0.050 & 0.000 \\
\hline $\begin{array}{l}\text { American Kestrel } \\
\text { (Falco sparverius) }\end{array}$ & 5.30 & 0.000 & 0.000 & 0.126 \\
\hline $\begin{array}{l}\text { Killdeer } \\
\text { (Charadrius vociferus) }\end{array}$ & 3.15 & 0.000 & 0.000 & 0.075 \\
\hline $\begin{array}{l}\text { Solitary Sandpiper } \\
\text { (Tringa solitaria) }\end{array}$ & 0.00 & 0.000 & 1.000 & 0.024 \\
\hline $\begin{array}{l}\text { Common Snipe } \\
\text { (Gallinago gallinago) }\end{array}$ & 3.85 & 0.000 & 0.000 & 0.092 \\
\hline $\begin{array}{l}\text { American Woodcock } \\
\text { (Scolopax minor) }\end{array}$ & 1.15 & 0.000 & 0.058 & 0.000 \\
\hline $\begin{array}{l}\text { Common Nighthawk } \\
\text { (Chordeiles minor) }\end{array}$ & 2.95 & 0.000 & 0.000 & 0.070 \\
\hline $\begin{array}{l}\text { Yellow-bellied Sapsucker } \\
\text { (Sphyrapicus varius) }\end{array}$ & 32.65 & 0.694 & 1.290 & 0.276 \\
\hline $\begin{array}{l}\text { Downy Woodpecker } \\
\text { (Picoides pubescens) }\end{array}$ & 30.65 & 0.346 & 0.100 & 0.468 \\
\hline $\begin{array}{l}\text { Hairy Woodpecker } \\
\text { (Picoides villosus) }\end{array}$ & 27.40 & 0.294 & 0.145 & 0.401 \\
\hline $\begin{array}{l}\text { Black-backed Woodpecker } \\
\text { (Picoides arcticus) }\end{array}$ & 1.00 & 0.038 & 0.000 & 0.000 \\
\hline $\begin{array}{l}\text { Northern Flicker } \\
\text { (Colaptes auratus) }\end{array}$ & 29.25 & 0.037 & 0.000 & 0.539 \\
\hline $\begin{array}{l}\text { Piliated Woodpecker } \\
\text { (Dryocopus pileatus) }\end{array}$ & 6.80 & 0.148 & 0.098 & 0.024 \\
\hline
\end{tabular}


Eastern Wood-Pewee

(Contopus virens)

Yellow-bellied Flycatcher

(Empidonax flaviventris)

Alder Flycatcher

(Empidonax alnorum)

Least Flycatcher

(Empidonax minimus)

Blue-headed Vireo

(Vireo solitarius)

Philadelphia Vireo

(Vireo philadelphicus)

Red-eyed Vireo

(Vireo olivaceus)

Gray Jay

(Perisoreus canadensis)

Blue Jay

(Cyanocitta cristata)

Black-capped Chickadee

(Poecile atricapillus)

Boreal Chickadee

(Poecile hudsonica)

Red-breasted Nuthatch

(Sitta canadensis)

Brown Creeper

(Certhia americana)

Winter Wren

(Toglodytes troglodytes)

Golden-crowned Kinglet

(Rgulus satrapa)

Ruby-crowned Kinglet

(Regulus calendula)

Veery

(Catharus fuscescens)

Swainson's Thrush

(Catharus ustulatus)

Hermit Thrush

(Catharus guttatus)

American Robin

(Turdus migratorius)

\subsection{5}

36.60

111.60

149.9

20.40

34.50

244.40

12.35

9.85

78.75

14.40

23.85

23.85

46.30

214.30

21.25

81.20

98.85

38.35

21.85
0.021

0.817

0.000

0.000

5.208

0.245

0.785

0.323

0.865

0.210

0.827

5.080

2.889

0.235

0.100

0.101

0.094

0.100

0.129

0.752

1.230

0.824

0.415

0.100

0.038

0.826

0.000

0.056

0.881

0.000

0.023

1.053

0.510

0.421

6.762

1.720

0.098

0.35

0.333

0.131

0.000

0.000

0.511

$$
2.573
$$

3.590

0.311

0.137

0.685

0.502

0.000

0.525

0.270 
Cedar Waxwing

(Bombycilla cedrorum)

Tennessee Warbler

(Vermivora peregrina)

Orange-crowned Warbler

(Vermivora celata)

Nashville Warbler

(Vermivora ruficapilla)

Norther Parula

(Parula americana)

Chestnut-sided Warbler

(Dendroica pensylvanica)

Magnolia Warbler

(Dendroica magnolia)

Cape May Warbler

(Dendroica tigrina)

Black-throated Blue Warbler

(Dendroica caerulescens)

Yellow-rumped Warbler

(Dendroica coronata)

Black-throated Green

Warbler

(Dendroica virens)

Blackburnian Warbler

(Dendroica fusca)

Bay-breasted Warbler

(Dendroica castanea)

Black-and-white Warbler

(Mniotilta varia)

American Redstart

(Setophaga ruticilla)

Ovenbird

(Seiurus aurocapilla)

Connecticut Warbler

(Oporornis agilis)

Mourning Warbler

(Oporornis philadelphia)

Common Yellowthroat

(Geothlypis trichas)
1.85

449.10

0.000

0.000

0.068

0.90

7.246

2.988

4.497

119.00

0.035

0.000

0.000

0.771

0.283

1.829

2.20

0.085

0.000

0.000

271.35

0.002

0.348

6.294

296.15

2.715

0.500

4.619

94.75

3.194

0.195

0.186

5.35

0.162

0.058

0.000

115.05

2.285

0.000

0.711

40.50

1.342

0.180

0.048

51.65

1.987

0.000

0.000

403.40

11.123

3.938

0.844

121.15

0.767

1.533

1.680

129.65

0.033

3.870

1.224

260.90

4.035

6.798

0.477

1.00

0.039

0.000

0.000

124.80

0.000

1.108

2.733

7.45

0.000

0.000

0.177 


\begin{tabular}{lcccc}
\hline $\begin{array}{l}\text { Wilson's Warbler } \\
\text { (Wilsonia pusilla) }\end{array}$ & 19.00 & 0.029 & 0.060 & 0.435 \\
$\begin{array}{l}\text { Canada Warbler } \\
\text { (Wilsonia canadensis) }\end{array}$ & 74.85 & 1.152 & 1.005 & 0.590 \\
$\begin{array}{l}\text { Scarlet Tanager } \\
\text { (Piranga olivacea) }\end{array}$ & 5.90 & 0.245 & 0.000 & 0.024 \\
$\begin{array}{l}\text { Chipping Sparrow } \\
\text { (Spizella passerina) }\end{array}$ & 5.95 & 0.000 & 0.020 & 0.132 \\
$\begin{array}{l}\text { Lincoln's Sparrow } \\
\text { (Melospiza lincolnii) }\end{array}$ & 0.000 & 0.000 & 0.119 \\
$\begin{array}{l}\text { White-throated Sparrow } \\
\text { (Zonotrichia albicollis) }\end{array}$ & 318.90 & 0.633 & 0.645 & 0.058 \\
$\begin{array}{l}\text { Dark-eyed Junco } \\
\text { (Junco hyemalis) }\end{array}$ & 4.75 & 0.071 & 0.000 & 0.208 \\
$\begin{array}{l}\text { Rose-breasted Grosbeak } \\
\text { Pheucticus ludovicianus) }\end{array}$ & 33.35 & 0.035 & 1.185 & 0.150 \\
$\begin{array}{l}\text { Purple Finch } \\
\text { (Carpodacus purpureus) }\end{array}$ & 39.75 & 0.954 & 0.433 & 0.016 \\
$\begin{array}{l}\text { Pine Siskin } \\
\text { (Carduelis pinus) }\end{array}$ & 7.75 & 0.273 & 0.000 & 0.000 \\
$\begin{array}{l}\text { Evening Grosbeak } \\
\text { (Coccothraustes vespertinus) }\end{array}$ & 19.35 & 0.667 & 0.100 & \\
\hline
\end{tabular}

